\title{
Management of effluents and waste from pharmaceutical industry in Minas Gerais, Brazil
}

\author{
Eleonora Deschamps ${ }^{1, *}$, Olivia Vasconcelos ${ }^{2}$, Lisete Lange ${ }^{2}$, Claudio Luis Donnici ${ }^{3}$, \\ Merces Coelho da Silva ${ }^{4}$, Juliana Aparecida Sales ${ }^{3}$
}

\author{
${ }^{1}$ Departmento de Engenharia Ambiental, Universidade FUMEC, ${ }^{2}$ Departamento de Engenharia Sanitária e Engenharia \\ Ambiental, ${ }^{3}$ Departamento de Química/ICEx, Universidade Federal de Minas Gerais,, ${ }^{4}$ Universidade Federal de Itajubá
}

\begin{abstract}
Today the management of solid waste and wastewater is a major concern for humanity. In the last decade, traces of pharmaceuticals have been reported in the water cycle and have raised concerns among regulators, water suppliers and the public regarding the potential risks to human health. This study evaluated solid waste management in the state of Minas Gerais and concluded that the main fate of hazardous waste has been incineration, while the non-hazardous waste has been recycled or sent to landfills. However, complaints to the Environmental Agency - FEAM have indicated that a significant number of companies just send their hazardous wastes to landfills or even to garbage dumps, thus highlighting the urgent need for adequate waste management in Minas Gerais. Most of the pharmaceutical companies in Minas Gerais use conventional wastewater treatment. Mass spectrometry with electrospray ionization (ESI-MS) showed that the treatment routes adopted by the two 2 selected pharmaceutical industries were not effective enough since residues and degradation products of antibiotics were detected. The physicochemical analysis of the effluents showed variability in their characteristics, which may influence their treatability. The degradation assay with Fenton's reagent stood out as a promising route in achieving a higher removal capacity compared to the conventional treatment. This study contributes to enhancing our knowledge of the management of wastewater as well as of solid waste from the pharmaceutical industry in Minas Gerais and points out the need for further research.
\end{abstract}

Uniterms: Pharmaceutical industry/management of waste. Solid waste/management/pharmaceutical industry. Waste water/management/pharmaceutical industry. Brazil/pharmaceutical industry.

\begin{abstract}
Atualmente, a gestão de resíduos sólidos e águas residuais é uma grande preocupação para a humanidade. Na ultima década, a detecção de traços de medicamentos no ciclo da água tem sido reportada e tem gerado preocupação entre os agentes reguladores, fornecedores de água e público devido os riscos potenciais para a saúde humana. As empresas farmacêuticas, em Minas Gerais, aplicam tratamentos convencionais para as águas residuais e não há praticamente avaliação sobre a eficiência de remoção de resíduos de antibióticos. Este estudo avaliou a gestão de resíduos sólidos e concluiu que o destino principal foi, para o caso de resíduos perigosos, a incineração e, para os não perigosos, a reciclagem e o aterro sanitário. No entanto, denúncias apresentadas à Agência Ambiental - FEAM indicam que número significativo de empresas envia seus resíduos perigosos para aterros sanitários e até mesmo para lixões, ressaltando, assim, a necessidade urgente de adequada gestão dos resíduos gerados. A espectrometria de massas com ionização electrospray (ESI-MS) mostrou que a rota de tratamento convencional adotada por duas empresas do setor selecionadas não foi suficientemente eficaz, uma vez que resíduos e fragmentos de antibióticos foram detectados. Os resultados da caracterização físico-química de efluentes evidenciaram suas características variáveis, que podem influenciar a sua tratabilidade. O ensaio de degradação com o reagente Fenton destaca-se como caminho promissor para alcançar maior remoção. Este estudo contribuiu para elevar o nível de conhecimento no gerenciamento de águas residuais e resíduos sólidos da indústria farmacêutica no estado de Minas Gerais e evidenciou a necessidade de estudos mais detalhados.
\end{abstract}

Unitermos: Indústria farmacêutica/gestão de resíduos. Resíduos sólidos/gestão/indústria farmacêutica. Águas residuárias/gestão/indústria farmacêutica. Brasil/indústria farmacêutica.

*Correspondence: E. Deschamps. FUMEC University. Rua Cobre, 200, 30310-190 - Belo Horizonte - Minas Gerais, Brasil. E-mail: deschamps.deschamps@gmail.com 


\section{INTRODUCTION}

Although the production of pharmaceuticals in massive quantities has been ongoing for many decades already, it was only in the past decade that scientific studies worldwide have increasingly examined associated effluent and waste generation and their respective impact. Many surveys and studies have confirmed the presence of pharmaceuticals in effluents, municipal wastewaters, surface waters, groundwater and, to a lesser extent, drinking water. The ongoing global process of urbanization and population growth has increased the demand for clean water, leading to an increase in the volume of effluent to be treated (Bolong et al., 2009).

There is also a growing demand for new products such as antibiotics, which leads to an increase in new emerging contaminants released into the environment, typically at levels in the nanogram to low microgram per liter range, often without any knowledge of potential related risks to humans and damage to ecosystems. Antibiotics were recently ranked as a major risk group because of their high toxicity to algae and bacteria, even at low concentrations. These risks include an increase in the occurrence of fatal cases of hospital-borne infections with such pathogens that develop resistance towards antibiotics (Hernando et al., 2006; Watkinson et al., 2009).

A preliminary survey of the databases of the Environmental Agency of Minas Gerais state (FEAM) in the licensing process of the pharmaceutical industry, showed inconsistencies in data on the monitoring of solid waste production as well as noncompliance with the requirements to meet effluent discharge regulations. Inspections in the industries found that waste management is still in its infancy and that the large diversity in production results in the generation of a highly fluctuating effluent composition. This greatly impairs the efficiency of current treatment systems.

It is worth mentioning that in Brazil there is no legislation that limits the release of so-called emerging contaminants. Studies in Minas Gerais on the removal of pharmaceutical residues, especially residual antibiotics in effluents, are rare. The pharmaceutical companies in Minas Gerais use conventional treatment, and there is no evaluation of removal efficiency. This scenario explains the importance of this work aimed at evaluating solid waste management by the pharmaceutical industry as well as characterizing the generated effluents, developing analytical methods for detecting the presence of residual antibiotics and degradation products, and testing alternative or complementary treatments for these effluents.

\section{MATERIAL AND METHODS}

\section{Data survey}

The study began with the evaluation of the management of solid waste generated by the pharmaceutical industry in Minas Gerais State based on the data from FEAM. This was performed by an extensive data survey, tapping various sources, such as i) the outstanding database of FEAM, more specifically the production processes of the companies, ii) the effluent and solid waste monitoring reports of environmental licenses, iii) the records of monitoring and inspections of businesses, and iv) reports of industrial inventories of solid waste for the years 2003, 2007, 2008, 2009 and 2010.

\section{Pharmaceutical companies}

Two Minas Gerais-based pharmaceutical companies, company 1 and company 2, holding environmental certifications, were selected to be partners in this work. Based on their environmental commitment, the companies were visited to study the production process and the generation of waste and effluents, as well as the respective wastewater treatment plants. Effluents, generated in the production lines of antibiotics, were collected at three different times of the year and also before and after the treatment plant effluent. Both produce a wide variety of drugs, among them antimicrobial drugs (antibiotics) and both have an Effluent Treatment Plant (ETP) prior to discharge in the environment. While company 1 segregates the effluent generated at the line of antibiotics from the others and treats it in batches, company 2 produces three different antibiotics, does not segregate the antibiotic effluent from the others, and treats effluents continuously. At the time of the study, no one had a performance evaluation of their respective ETPs.

Company 1 produces the antibiotic amoxicillin (AMO), which belongs to the beta-lactam class. Company 2 produces the antibiotics norfloxacin (NOR), sulfaguanidine (SG) and sulfadiazine (SD). Company 1 treats the effluent through the hydrolysis of the beta-lactam ring, abruptly changing its $\mathrm{pH}$. The effluent $\mathrm{pH}$ in the ETP rises from 3.5 to values between 9 and 12 . After this treatment, the $\mathrm{pH}$ is adjusted to $\mathrm{pH} 7.0$ to 8.5 , at which the effluent is then suitable for directly discharged into the river.

\section{ESI-MS and GC experiments}

Chemical analyses were performed using a Finnigan Surveyor Plus Auto Sample gas chromatograph (GC) 
(ThermoScientific, San Jose, CA, USA) and Supelco C18 column (Sigma Aldrich, Bellefonte, PA, USA) with 3- $\mu \mathrm{m}$ particle size and L x I.D. of $15 \mathrm{~cm}, 2.1 \mathrm{~mm}$. HPLC-grade acetonitrile and methanol (Vetec, Sao Paulo, Brazil) along with Milli-Q water (Millipore, Milford, MA, USA) were used to prepare the solutions. The analytical conditions were isocratic elution with methanol/Milli-Q water (8:2 $\mathrm{v} / \mathrm{v}$ ). The identification of the eluted compounds was performed by mass spectrometry with electrospray ionization (ESI-MS) (ThermoScientific, San Jose, CA, USA). Mass spectra were obtained from an average of 50 scans, each one requiring $0.02 \mathrm{~s}$, operating in the positive ion mode. The analysis conditions were: spray voltage of $5 \mathrm{kV}$, sheath gas $\left(\mathrm{N}_{2}\right)$ flow rate of 20 units, auxiliary gas flow rate of 15 (arbitrary units), capillary voltage of $44 \mathrm{~V}$, and heat capillary temperature of $280^{\circ} \mathrm{C}$, and tube lens voltage of 119 V (Oliveira et al., 2012). The solutions were directly injected into the ESI source at a flow rate of $20 \mu \mathrm{L} / \mathrm{min}$ using a $500 \mu \mathrm{L}$ microsyringe (Hamilton, Reno, NV, USA).

Table I shows the analysis conditions for the mass spectrometer (MS-ESI).

TABLE I - Conditions of analysis in the mass spectrometer for the antibiotics

\begin{tabular}{lcccc}
\hline & \multicolumn{4}{c}{ Analytes } \\
\cline { 2 - 5 } Analysis conditions & AMO & NOR & SD / SG $\begin{array}{c}\text { Mixture } \\
\text { NOR, SD } \\
\text { and SG }\end{array}$ \\
\hline Voltage $(\mathrm{kV})$ & 5.0 & 5.0 & 5.0 & 5.5 \\
Carrier gas $(\mathrm{mL} / \mathrm{min})$ & 25 & 15 & 20 & 5 \\
Auxiliary gas $(\mathrm{mL} / \mathrm{min})$ & 0 & 0 & 10 & 0 \\
Lenses & 69.8 & -125.3 & 74.7 & 94.7 \\
\hline Ne: Capily
\end{tabular}

Note: Capillary temperature $=285^{\circ} \mathrm{C}$

Stock standard solutions of the analytes AMO, SG, $\mathrm{SD}$ and NOR were prepared with concentration in the range 50 to $100 \mathrm{mg} / \mathrm{L}$. The standards were diluted in Milli-Q water to obtain concentrations below $1.0 \mathrm{mg} / \mathrm{L}$ for analysis by ESI-MS. The stock solutions and diluted standards were stored in amber vials in a refrigerator for later use.

For the effluents of companies 1 and 2, standard solutions of each antibiotic were prepared individually at a concentration of $500 \mu \mathrm{g} / \mathrm{L}$ and a standard solution containing the four analytes (AMO, NOR, SD and SG) at a concentration of $500 \mu \mathrm{g} / \mathrm{L}$ for calibration of the operating conditions of mass spectrometry of the samples (Oliveira et al., 2012). The standard solutions were prepared using samples of antibiotics that were kindly provided by the companies.

\section{Characterization of industrial wastewater}

The extraction of the effluent samples was performed using the method described by Goulart (2004), making use of low-temperature extraction. Before being submitted to the extraction process, samples were filtered using a simple filtration system. Accordingly, $10 \mathrm{~mL}$ of the filtrate were added to a test tube with $20 \mathrm{~mL}$ of HPLC-grade acetonitrile. The test tubes were placed in a freezer for $24 \mathrm{~h}$. Afterwards, the liquid part obtained (solute concentrated in acetonitrile) was filtered using a $0.45-\mu \mathrm{m}$ Millipore filter. The filtrate was transferred to amber vials and stored in the refrigerator.

Parameters to characterize the effluents were $\mathrm{pH}$, redox potential, conductivity, alkalinity, total organic carbon (TOC), total carbon (TC), total nitrogen (TN), ammonia nitrogen, nitrate, nitrite, and sulfate; all were determined by conventional methods, established by the Standard Methods for the Examination of Water and Wastewater (APHA, 2005).

The determination of dissolved organic carbon and total nitrogen were performed on a VCSH Shimadzu TOC instrument (Shimadzu Scientific Instruments, Kyoto, Japan) with the measurement unit for total nitrogen and TNM-1 autosampler ASI-V. The samples were previously filtered through $45-\mu \mathrm{m}$ membranes. Nitrate and nitrite were determined by ion chromatography (ThermoScientific, San Jose, CA, USA) on a Dionex ICS1000 chromatograph, IonPac AS 22 column, $2 \mathrm{~mm}$ x $250 \mathrm{~mm}$, with separation via ion exchange using isocratic elution and conductivity detection with ion suppression,. The operation conditions were typically as follows: flow rate $=0.25$ $\mathrm{mL} / \mathrm{min} . \mathrm{L}, 0.8 \mathrm{mmol} / \mathrm{L} \mathrm{NaHCO}_{3}$ and $4.5 \mathrm{mmol} / \mathrm{L} \mathrm{Na}_{2} \mathrm{CO}_{3}$.

\section{Degradation tests with Fenton's reagent}

To investigate the effluents generated at different treatment stages in the production plant of amoxicillin, degradation tests were performed by advanced oxidation with Fenton's reagent. The tests were conducted at room temperature, at $\mathrm{pH} 3.5$, and the ratio of $\mathrm{H}_{2} \mathrm{O}_{2}$ : C was set at $7: 1$, this value being close to stoichiometric, and $\mathrm{H}_{2} \mathrm{O}_{2}: \mathrm{C}$ was $10: 1$ to work with $40 \%$ excess peroxide. The mineralization of AMO during the experiments was evaluated by measuring the decay of total organic carbon.

\section{RESULTS AND DISCUSSIONS}

\section{Management of solid waste by the pharmaceutical industries in Minas Gerais State}

The pharmaceutical industry in Minas Gerais consists 
of 114 companies and employs approximately 10,800 people. It focuses almost exclusively on the domestic market and its main products are generic drugs and herbal medicines. Most companies are concentrated in the Metropolitan Region of Belo Horizonte (50\%), about $20 \%$ are located in southern Minas Gerais, and the rest are distributed in the rest of the state (Silva, 2011, personal communication). There are, however, many more products that all contribute to the wide variety of inputs and raw materials and particularly to the generation of solid wastes and industrial effluents, thus directly influencing their management.

The ten most-frequently generated waste types represent almost the entire quantity of waste generated. Among those ten are three waste types, classified according to ABNT 10.004/2004 as hazardous, which correspond to $73.6 \%$ of the total of waste generated (FEAM, 2010). In total, we observed the generation of about 100 different types of solid waste. Annually, the companies are required to send to FEAM an inventory of industrial solid wastes. This inventory discerns between those solid wastes that remain in-house and those with an external destination. The main form of waste disposal has been the incineration of hazardous waste (Class I). Non-hazardous waste (Class II) is sent to both recycling and landfills. However, complaints to the environmental agency FEAM have indicated that a significant number of companies do not properly manage their wastes, where the disposal of hazardous waste is usually in landfills and even garbage dumps.

\section{Identification of amoxicillin metabolites}

Amoxicillin (AMO) has a structure with three chiral centers, which accounts for the existence of eight optically active isomers. However, only AMO has antibacterial activity. Additionally, the presence of a beta-lactam ring makes this molecule readily cleavable. Two major metabolites of AMO are amoxicilloic acid (AMA) and amoxicillin diketopiperazine-2,5-dione (DIKETO). It is known, however, that AMA has a high allergenic potential (Reyns et al., 2008).

Figure 1 shows the main products obtained from the acidic or basic hydrolysis of AMO. In the acidic medium,
AMO hydrolysis may lead to the formation of DIKETO. The existence of this isomer in ETPs can complicate the analysis of AMO by conventional analytical techniques, both for ultraviolet (UV) detection and mass spectrometry (MS). However, the presence of the fragment due to a mass/ charge $(\mathrm{m} / \mathrm{z})$ of 149 is characteristic of AMO, which is identified whether or not amoxicillin is present in the medium.

It is known that the identification of beta-lactam (BL)-type antibiotics may be impaired due to the degradation of these compounds. BL rings are susceptible to hydrolysis due to their tendency to destabilize and also due to the electrophilicity of the carbonyl carbon, which can undergo nucleophilic attack. In some methods reported in the literature, many of these antibiotics show a low recovery rate $(<30 \%)$ and the inability to detect the analytes is mostly explained by the low rates of recovery in the extraction procedure (Watkinson et al., 2007). Despite the reported problems in detecting BL antibiotics, there are reports on the presence of amoxicillin in municipal sewage (Boxall et al., 2003; Watkinson et al., 2009; CALAMARI et al., 2003), of ampicillin (AMP), mezlocillin (MZC), flucloxacillin (FXC) and piperacillin (PPC) in surface waters on the order of $48 \mathrm{ng} / \mathrm{L}$ and AMO in river water at concentrations less than $10 \mathrm{ng} / \mathrm{L}$ (Christian et al., 2003).

Several analytical methods to determine beta-lactam antibiotics in the environment in different matrices (in its natural form, soil and waste water) are reported in the literature. Most methods employ liquid chromatography coupled with a mass spectrometer (LC-MS) or LC-MSMS, due to its high sensitivity and ability to provide confirmation of the compounds being detected. The mass spectrometers used are for the most part single or triple quadrupole. In the present work, electrospray ionization mass spectrometry (ESI-MS) (Oliveira et al., 2012) was employed along with the extraction method described by Goulart (2004).

\section{Effluent analyses from company 1 by ESI-MS}

The analysis of the pattern of amoxicillin operating in the positive ion mode ESI $(+)$ showed the two peaks
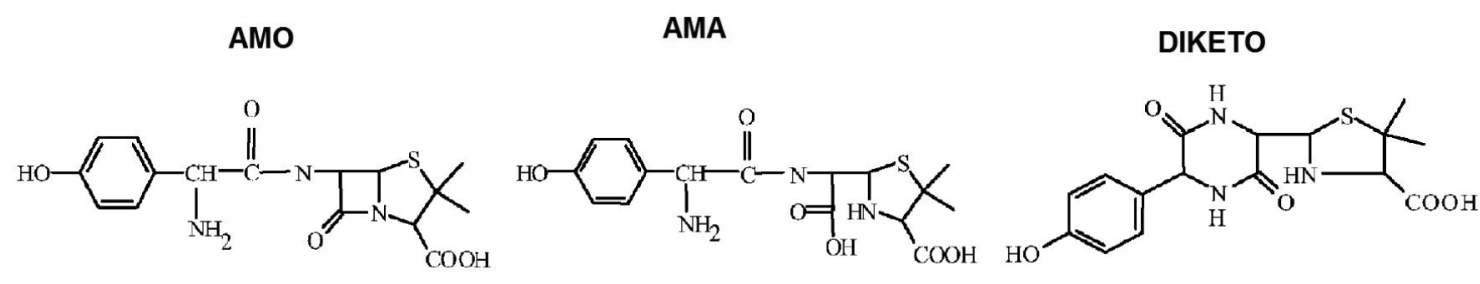

FIGURE 1 - Chemical structure of amoxicillin (AMO) and its metabolites, amoxicilloic acid (AMA) and amoxicillin diketopiperazine-2,5-dione (DIKETO). 
characteristic of this substance: $\mathrm{m} / \mathrm{z} 366$, together with the AMO of the protonated molecular ion $[\mathrm{M}+\mathrm{H}]^{+}$and the peak with $\mathrm{m} / \mathrm{z} 349$, associated with the fragment ion $[\mathrm{M}+\mathrm{H}]^{+}$losing a molecule of $\mathrm{NH}_{3}$ (Figure 2). Effluent samples were collected before and after treatment. The preliminary results indicate the persistence of the drug. This prompted suggested adjustments in the ETE to improve the treatment efficiency. The company readily accepted the suggestions and increased the concentration of sodium hydroxide $(\mathrm{NaOH})$ from $40 \mathrm{~g} / \mathrm{L}$ to 80 $\mathrm{g} / \mathrm{L}$, which resulted in a $\mathrm{pH}$ increase from 12 to 13 . The company also increased the residence time from 20 to 40 minutes without change in the agitation form in the treatment reactor tank.

The molecular ion with $\mathrm{m} / \mathrm{z} 366$ corresponding to the starting material AMO (or in the rearranged forms AMOR1/R2) was found in all samples analyzed. However, other fragments were detected, such as that with $\mathrm{m} / \mathrm{z} 349$ (AMO-F1: loss of $\mathrm{NH}_{3}, 17 \mathrm{~g} / \mathrm{mol}$ and one corresponding to the final product, with $\mathrm{m} / \mathrm{z} 149$ (AMO-F2), and this product was obtained from the cleavage of the rearranged intermediate (AMO-R1). These data show that AMO was not totally degraded in more hydrophilic compounds, but with no cleavage or oxidation of the aromatic moiety. Besides, it is noteworthy that amoxicilloic acid (AMA) (m/z $384, \mathrm{M}-\mathrm{H}+$ ), a powerful allergenic agent, was detected.
In fact, AMA is one of the most common metabolites of alkaline hydrolysis of AMO, and there is no official information about the allowable limits of this compound in the environment.

Figure 3 displays representative ESI mass spectra in the positive ion mode, ESI(+)-MS, of an acetonitrile solution of effluent of company 1 . As a common feature, the spectra of the effluents exhibit abundant ions of $\mathrm{m} / \mathrm{z} 385$, 349, 343 which characterized AMO and other fragments of AMO (Nägele, Moritz, 2005). These results showed that the alkaline hydrolysis treatment had not been effective since AMO residues and fragments characteristic of the antibiotic were also detected in the samples after the treatment.

\section{Effluent analyses from company 2 by ESI-MS}

Company 2 did not segregate the antibiotic effluent from the other effluents generated from the entire production of drugs, and treated continuously according to the conventional physicochemical treatment. The effluent is therefore a complex mixture containing several active ingredients from the entire production, which includes the effluents coming from the production lines of antibiotics and hormones. Figure 4 shows the mass spectrum by ESI $(+)$ of a standard mixture of NOR, SD and SG (Figure 4).
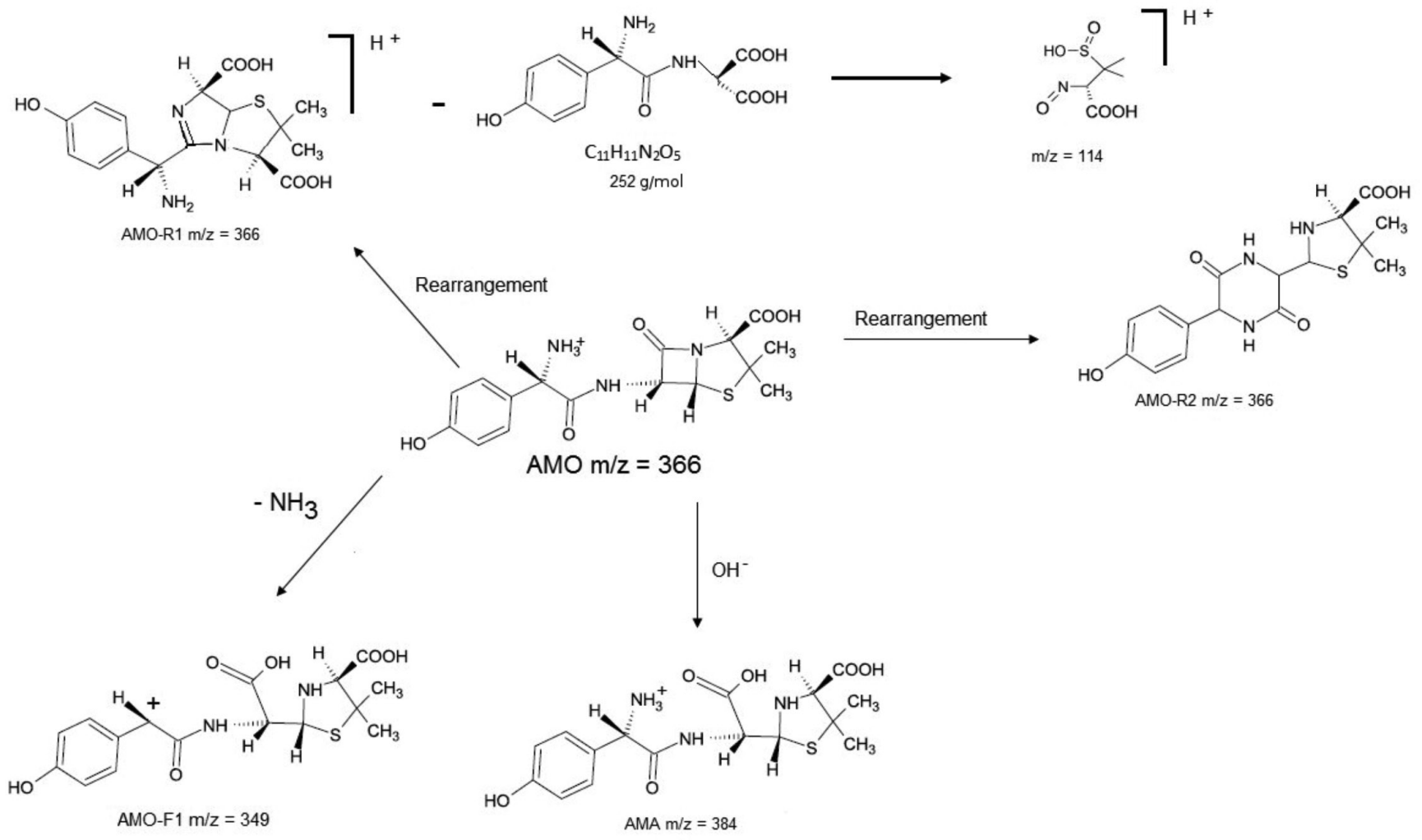

FIGURE 2 - Proposed degradation of AMO in effluents after alkaline hydrolysis. 
AMOX-COLETA-18-02-2010-APOS-TRATAMENTO_100223101857\#1-50 RT: 0.00-0.08 AV: 50 NL: 2.63E3

T: ITMS + c ESI Full ms [300.00-400.00]

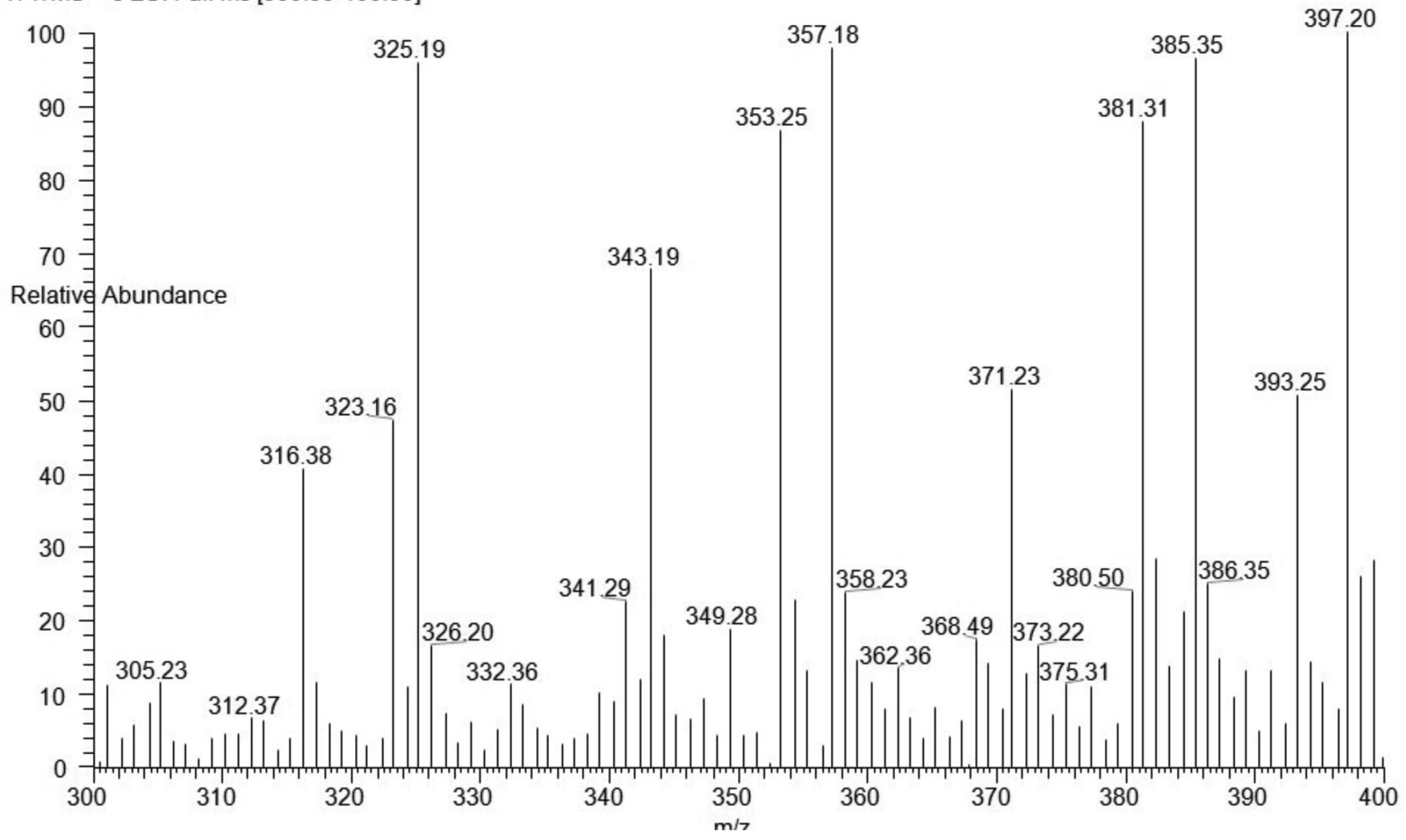

FIGURE 3 - Mass spectrum (ESI+) for company 1 effluents after alkaline hydrolysis.

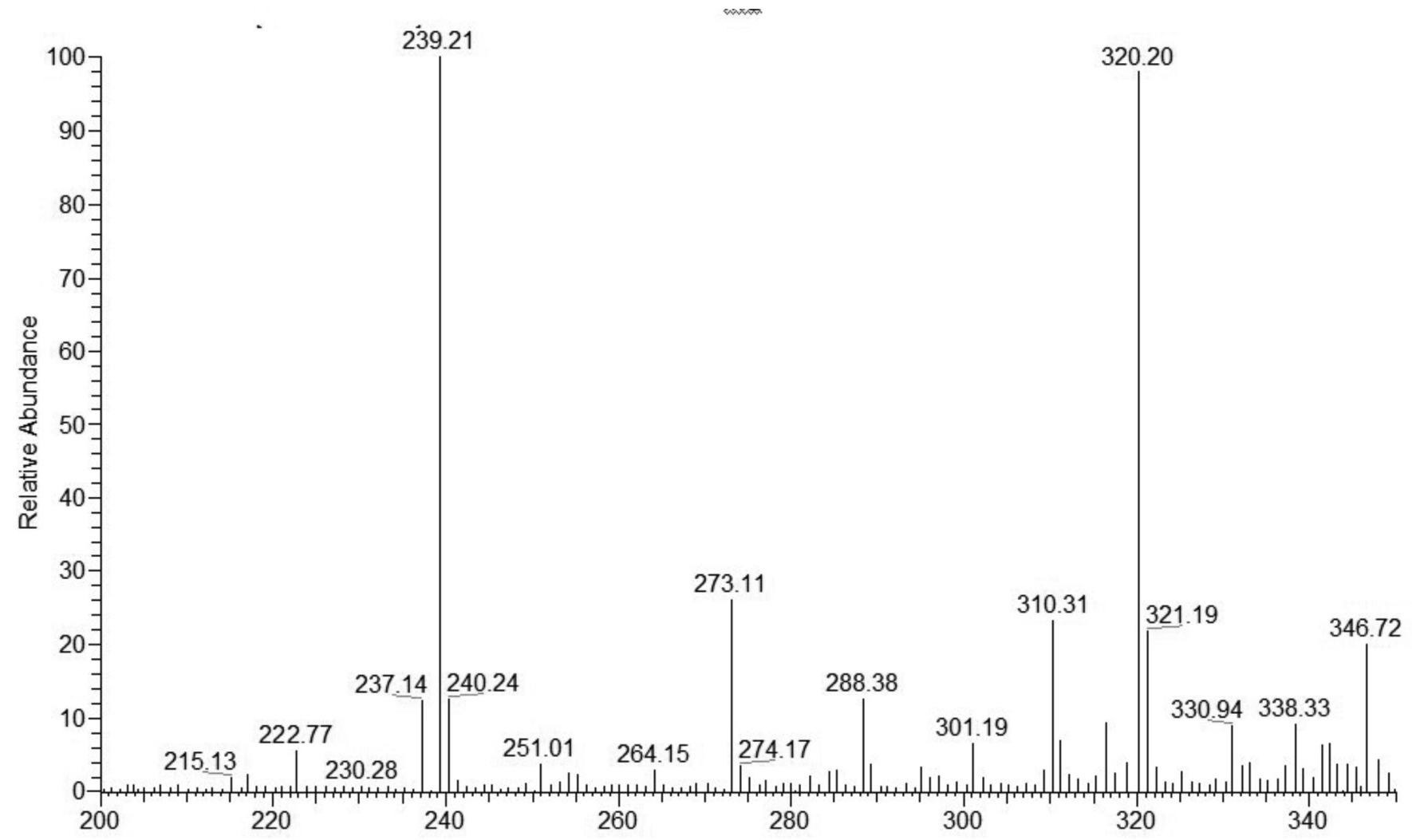

FIGURE 4 - Mass spectrum (ESI+) of a mixture of NOR, SD and SG reference materials at $500 \mu \mathrm{g} / \mathrm{L}$. 
The detection and identification of NOR, SD and SG in the effluents showed that they were not totally degraded to more hydrophilic compounds. The molecular ion with $\mathrm{m} / \mathrm{z} 215$ corresponded to the starting material SG (or in the rearranged forms SG), m/z 320 corresponded to $\mathrm{NO}$ (or in the rearranged forms NO), and m/z 273 was SD (Figure 5).
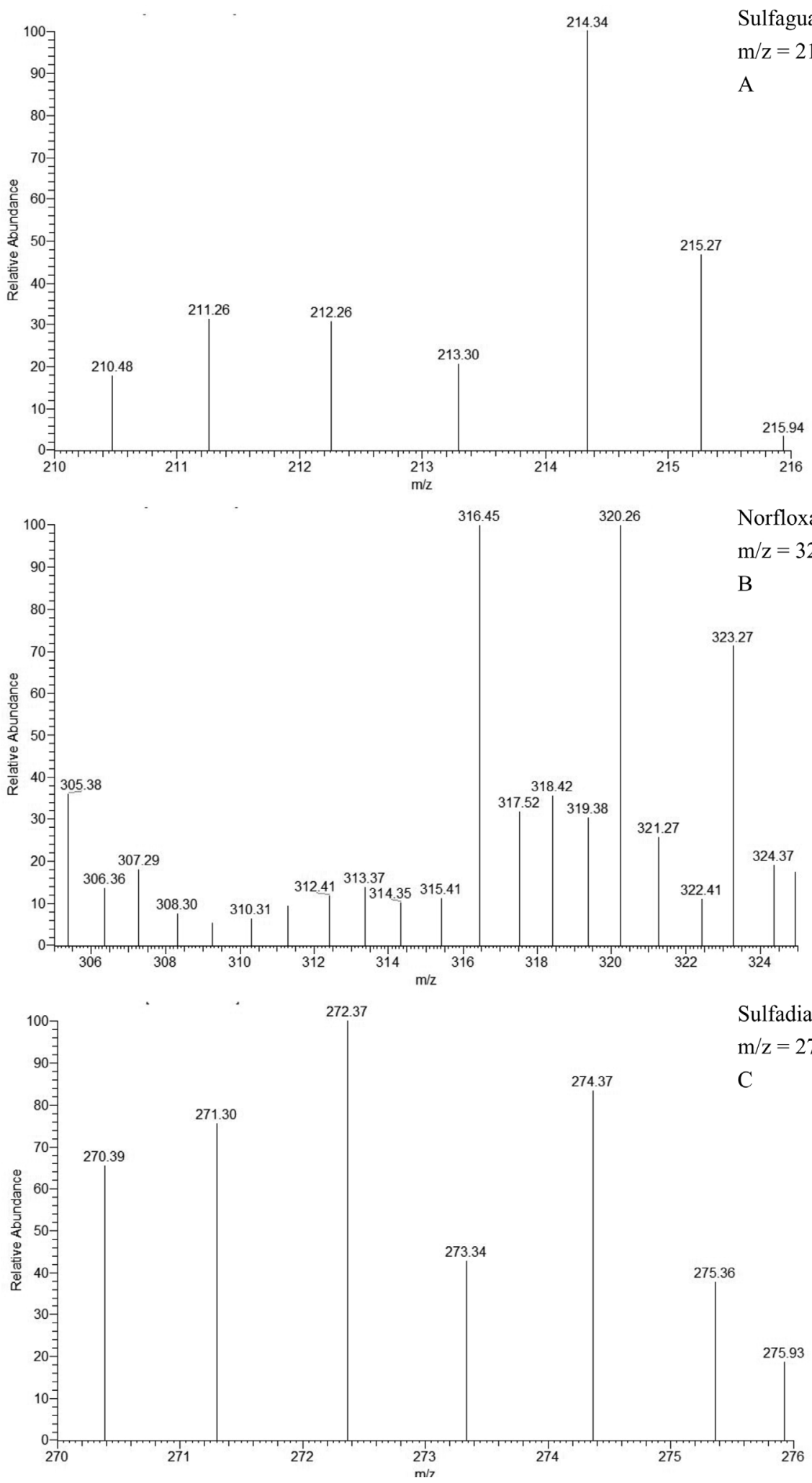

FIGURE 5 - Mass spectrum (ESI+) for effluents of company 2 after alkaline hydrolysis. 


\section{Characterization of industrial wastewater}

According to the effluent and solid waste monitoring reports of the environmental licenses in the database of FEAM, most of the pharmaceutical companies in Minas Gerais State do not characterize their generated waste and use conventional treatment methods. They do not develop efficient methods to indicate the presence of toxins before and after the release of effluents. The characterization of the effluent was performed with the effluent from the company 1 due to the fact that this company segregates the effluent generated in the production line of antibiotics, and therefore, it was less complex.

The industrial effluents were collected in July 2010 (E1), September 2010 (E2), and October 2010 (E3) and showed distinct characteristics, confirming seasonality in production stages. The level of DOC (dissolved organic carbon) of effluents E1, E2 and E3 in different stages of treatment was highly variable, with removal rates ranging from 6 to $97 \%$ DOC.

The removal of nitrogen in the three effluents studied was very low, which may indicate the presence of fragments of the molecule AMO in the effluent. Nitrogen in the molecule is linked to the AMO $\beta$-lactam ring and the thiazolidine ring, as well as amino groups. This may indicate that the treatment can break the $\beta$-lactam ring, but the degradation products of AMO remain in the effluent. $\mathrm{NO}_{2}$ was below the detection limit, supported by the value of the redox potential of the samples. The samples showed low conductivity values due to low ion concentrations in solution. The $\mathrm{Cl}^{-}$content was low, which minimizes its possible interference as a contender for the $\bullet \mathrm{OH}$ radical treatment with Fenton's reagent.

The results of the physicochemical characterization of the effluent showed variability in their characteristics, indicating that the batch formulation process showed significant differences, which may influence effluent treatability, corroborating the study of Mascolo et al. (2010).

\section{Degradation of the effluent (E1) by advanced oxidation process (AOP) with Fenton's reagent}

The effluents generated in different treatment stages in the amoxicillin production plant were submitted to degradation tests by advanced oxidation with Fenton's reagent with the effluent E3 for the points P1 (raw effluent) and P3 (effluent after acidification). The organic load found for E1 as DOC was $1484 \mathrm{mg} / \mathrm{L}$, and at E3 DOC was 770 $\mathrm{mg} / \mathrm{L}$. We evaluated their degradation via the photo-Fenton process and investigated the optimum conditions (Trovó et al., 2008; Ay, Kargi, 2010).
TABLE II - Characterization of the effluents E1, E2, E3, before hydrolysis

\begin{tabular}{lccc}
\hline Parameter & E1 & E2 & E3 \\
\hline TOC $(\mathrm{mg} / \mathrm{L})$ & 1484 & 486 & 770 \\
$\mathrm{~N}$ total $(\mathrm{mg} / \mathrm{L})$ & 15.1 & 24.5 & 26.3 \\
Condutivity $(\mu \mathrm{S})$ & 15.1 & 24.6 & 26.3 \\
Redox potential $(\mathrm{mV})$ & 770 & 521 & 510 \\
Chlorides $\mathrm{Cl}^{-}(\mathrm{mg} / \mathrm{L})$ & 15.6 & 23.9 & 1.10 \\
Sulfates $\mathrm{SO}_{4}{ }^{2-}(\mathrm{mg} / \mathrm{L})$ & 6.98 & 1.81 & 0.94 \\
Nitrate $\mathrm{NO}_{3}^{-}(\mathrm{mg} / \mathrm{L})$ & 1.19 & 1.67 & 1.23 \\
Nitrite $\mathrm{NO}_{2}^{-}(\mathrm{mg} / \mathrm{L})$ & $<0.05$ & $<0.05$ & $<0.05$ \\
\hline
\end{tabular}

Note: $\mathrm{NO}_{2}^{-}<0.05 \mathrm{mg} / \mathrm{L}$ : Limit of detection

The effluents studied in this research showed discrepant results, both in the degradation assay with Fenton's reagent and the determinations of DOC. There were no differences in physicochemical characteristics and DOC content for the three effluents studied, as shown by Mascolo et al. (2010). In advanced oxidation tests with Fenton's reagent the E1 effluent, collected at point P1, showed a DOC removal rate of $36 \%$, possibly indicating the presence of refractory fractions. For E3, collected at point $\mathrm{P} 1$, the removal rate was $74 \%$ DOC (Figure 6). Since the treatment process was carried out in batches, this type of effluent showed quite different physical and chemical characteristics. Melero et al. (2009) obtained a $59 \%$ reduction in TOC for a real wastewater with different active ingredients, which is treated by heterogeneous catalytic oxidation with $\mathrm{H}_{2} \mathrm{O}_{2}$ and iron oxide mesostructure materials.

For E3 (collected at the ETP outlet), the results indicated $85 \%$ removal of DOC, higher than the values found for E3 (collected at the ETP inlet), which showed a DOC removal rate of $70 \%$ (Figure 7 ). The tests were conducted at room temperature, at $\mathrm{pH} 3.5$, and the ratio $\mathrm{H}_{2} \mathrm{O}_{2}: \mathrm{C}$ was set at 7:1, close to the stoichiometric value, and 10:1 to work with $40 \%$ excess peroxide.

\section{CONCLUSIONS}

Advances in analytical technology have been a key factor driving enhanced detection of contaminants as well as improvements in the wastewater treatment process.

These results showed that the alkaline hydrolysis treatment was not effective since AMO residues and fragments characteristic of the antibiotic were also detected in the samples after treatment. The presence of ion $\mathrm{m} / \mathrm{z} 149$ can lead to two conclusions: i) AMO was present in the effluent (because degradation product 366 could be the 


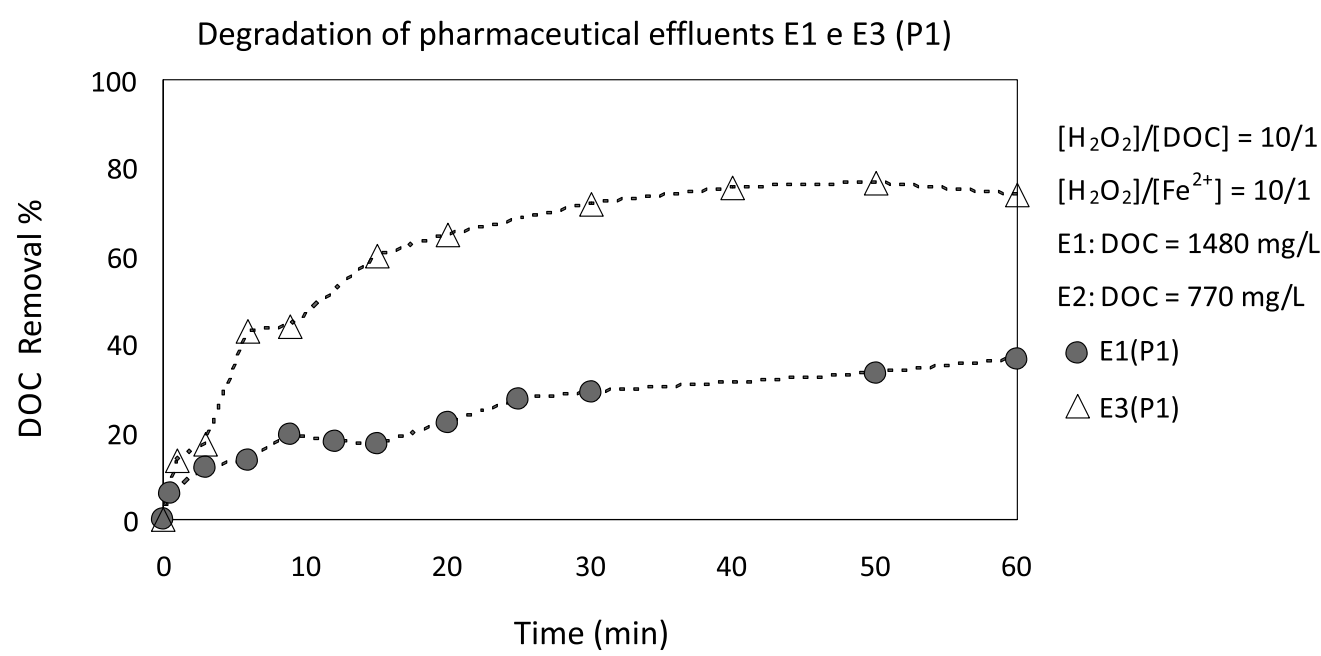

FIGURE 6 - DOC removal efficiencies in Fenton reactions in pharmaceutical wastewater E1 and E3, molar $\left[\mathrm{H}_{2} \mathrm{O}_{2}\right] /[$ DOC $]$ ratio $=$ $10: 1,\left[\mathrm{H}_{2} \mathrm{O}_{2}\right] /\left[\mathrm{Fe}^{2+}\right]$ ratio $=10: 1$ and $\mathrm{pH}=3.3$.

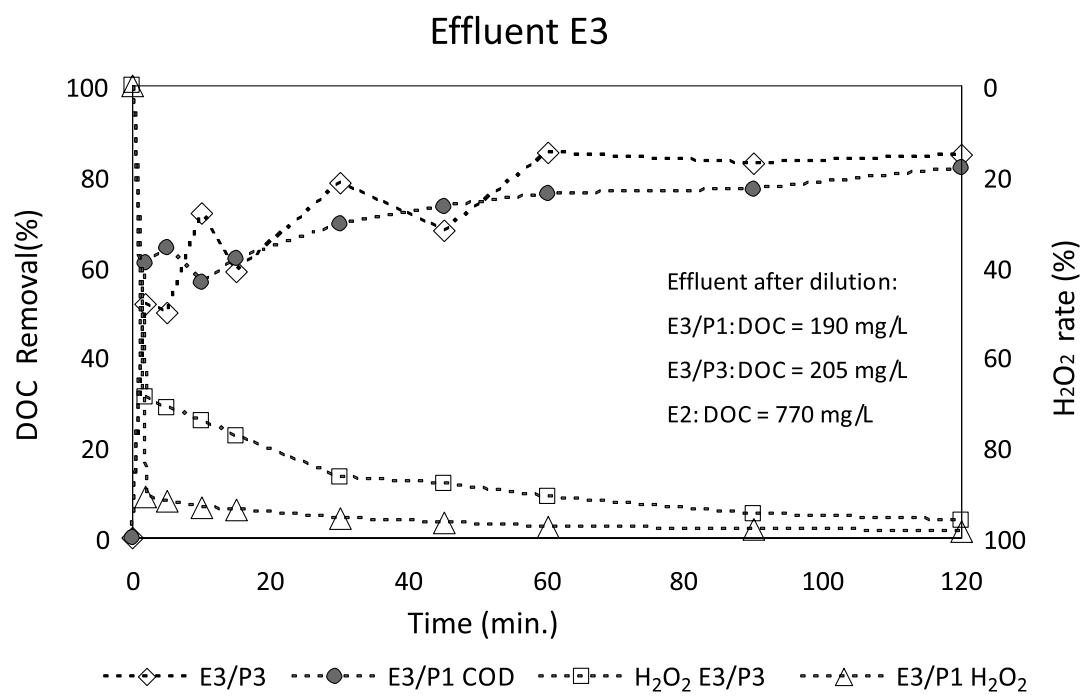

FIGURE 7 - Degradation of pharmaceutical wastewater $\mathrm{E} 3$ in Fenton reactions before and after alkaline hydrolysis treatment, molar $\left[\mathrm{H}_{2} \mathrm{O}_{2}\right] /[\mathrm{DOC}]$ ratio $=7: 1,\left[\mathrm{H}_{2} \mathrm{O}_{2}\right] /\left[\mathrm{Fe}^{2+}\right]$ ratio $=10: 1$, and $\mathrm{pH}=3.3$.

result of an isomer of $\mathrm{AMO}$ ) and ii) the AMO molecule was broken down.

It is important to highlight the identification of the presence of the characteristic degradation product amoxicilloic acid (AMA), which has a high allergenic potential. The results indicated that the treatment in both companies is still not effective and needs adjustments. The advanced oxidation processes associated with segregation stands out as a promising route.

As for solid waste disposal and main destination, the survey of the databases of FEAM indicated that a significant number of the companies send their hazardous waste to landfills and even to garbage dumps, thus highlighting the urgent need for an adequate waste management.
This study contributes to enhancing our knowledge of wastewater management issues and about solid waste from the pharmaceutical industry in Minas Gerais. There are undoubtedly many developments to come in the short-, medium- and even long-term so that Brazil can achieve a higher level of sustainability.

\section{ACKNOWLEDGEMENTS}

The authors thank Minas Gerais Research Foundation- FAPEMIG for financial support of the project TEC 1881/08, PRONEX EDT 479/07, PPM V 356/11 as well as for the scholarships awarded. Special thanks go to company 1 and company 2 and also to the Syndicate of 
Pharmaceutical Industries in Minas Gerais-Sindusfarq for the valuable partnership. The anonymous review work of the referees is deeply appreciated.

\section{REFERENCES}

APHA, AWWA, WEF. Standard Methods for the Examination of Water and Wastewater. American Public Health Association, 21 ed., Washington, D.C., USA, 2005.

AY, F.; KARGI, F. Advanced oxidation of amoxicillin by Fenton's reagent treatment. J. Hazard. Mater., v.179, p.622$627,2010$.

BOLONG, N.; ISMAILA, A.F.; SALIMB, M.R.; MATSUURA, T. A review of the effects of emerging contaminants in wastewater and options for their removal. Desalination, v.239, p.229-246, 2009.

BOXALL, A.B.A.; KOLPIN, D.W.; HALLING-SORENSEN, B.; TOLLS, J. Are veterinary medicines causing environmental risks? Environ. Sci. Technol., v.37, p.286294, 2003.

CALAMARI, D.; ZUCCATO, E.; CASTIGLIONI, S.; BAGNOTTI, R.; FANELLI, R. Strategic survey of therapeutic drugs in the rivers Po and Lambro in northern Italy. Environ. Sci. Technol., v.37, p.1241-1248, 2003.

CHRISTIAN, T.; SCHNEIDER, R.J.; FÄRBER, H.A.; SKUTLAREK, D.; MEYER,M.T.; GOLDBACH, H.E. Determination of antibiotic in manure, soil and surface waters. Acta Hydrochim. Hydrobiol., v.31, p.36-44, 2003.

FUNDAÇÃO ESTADUAL DO MEIO AMBIENTE- FEAM. Inventário de resíduos sólidos industriais e minerários. Belo Horizonte, 2010. 104 p.

GOULART, S.M. Extração de deltametrina e cipermetrina em leite e análise por cromatografia gasosa. Viçosa, 2004. 60 p. [Dissertation of Master Degree. Department of Chemistry, Federal University of Viçosa].

HERNANDO, M.D.; MEZCUA, M.; FERNANDEZ-ALBA, A.R.; BARCELO, D.; Environmental risk assessment of pharmaceutical residues in wastewater effluents, surface waters and sediments. Talanta, v.69, p.334-342, 2006.
MASCOLO, G.; BALEST, L.; CASSANO, D.; LAERA, G.; LOPEZ, A.; POLLICE, A.; SALERMO, C. Biodegradability of pharmaceutical industrial wastewater and formation of recalcitrant organic compounds during aerobic biological treatment. Biores. Technol., v.101, p.2585-2591, 2010.

MELERO, J.A.; MARTÍNEZ, F.; BOTAS, J.A.; MOLINA, R.; PARIENTE, M.I.; Heterogeneous catalytic wet peroxide systems for the of an industrial pharmaceutical wastewater. Water Res., v.43, p.4010-4018, 2009.

NÄGELE, E.; MORITZ, R. Structure elucidation of degradation products of the antibiotic amoxicillin with Ion Trap MS ${ }^{\mathrm{n}}$ and accurate mass determination by ESI TOF. J. Am. Soc. Mass Spectrom., v.16, p.1670-1676, 2005.

OLIVEIRA, S.R.; NOGUEIRA, L.J.; AUGUSTI, R.; STOIANOFF, M.A.R.; AGUILAR, C.M.; ROCHA, W.R.; DONNICI, C.L. Influence of oxidation state of sulfur on the dissociation of [Tz- $(\mathrm{CH} 2) n-\mathrm{S}(\mathrm{O}) \mathrm{m}-(\mathrm{CH} 2) \mathrm{n}-\mathrm{Tz}+\mathrm{Na}+]$ adducts generated by electrospray ionization $(\mathrm{Tz}=$ tetrazole ring; $\mathrm{n}=2,3 ; \mathrm{m}=0,1,2)$. Rapid Commun. Mass Spectrom. v. 26, p. $377-384,2012$.

REYNS, T.; CHERLET, M.; BAERE, S.; BACKER, P.; CROUBLES, S. Rapid method for the quantification of amoxicillin and its major metabolites in pig tissues by liquid chromatography-tandem mass spectrometry with emphasis on stability issues. J. Chromatogr. B., v.861, p.108-116, 2008.

SILVA, Geovane. Sindusfarq Minas Gerais, 2011 (personal communication). É necessário dados de publicação para que seja incluído.

TROVÓ, A.G.; MELO, S.A.; NOGUEIRA, R.F.P. Photodegradation of the pharmaceuticals amoxicillin, bezafibrate and paracetamol by the photo-Fenton process and application to sewage treatment plant effluent. $J$. Photochem. Photobiol. A., v.198, p.215-220, 2008.

WATKINSON, A.J.; MURBY, E.J.; KOLPIN, D.W.; COSTANZO, S.D. The occurrence of antibiotics in an urban watershed: from wastewater to drinking water. Sci. Total Environ., v.407, p.2711, 2009.

Received for publication on $09^{\text {th }}$ December 2011 Accepted for publication on $25^{\text {th }}$ October 2012 